Research Article

\title{
Cytotoxicity and Antiangiogenic Activity of Turbinaria ornata Agardh and Padina australis Hauck Ethanolic Extracts
}

\author{
Jenefa L. Canoy and Jayzon G. Bitacura \\ Department of Biological Sciences, Visayas State University, Visca, 6521-A Baybay City, Leyte, Philippines \\ Correspondence should be addressed to Jayzon G. Bitacura; jayzon.bitacura@vsu.edu.ph
}

Received 12 February 2018; Revised 29 June 2018; Accepted 3 July 2018; Published 6 August 2018

Academic Editor: José A. Sánchez-Alcázar

Copyright ( 2018 Jenefa L. Canoy and Jayzon G. Bitacura. This is an open access article distributed under the Creative Commons Attribution License, which permits unrestricted use, distribution, and reproduction in any medium, provided the original work is properly cited.

\begin{abstract}
Brown macroalgae species are constantly reported as potential sources of bioactive compounds useful in inhibiting cell proliferation and vascular formation. Thus, this study was conducted to determine and compare the in vitro cytotoxic activities of Turbinaria ornata Agardh and Padina australis Hauck ethanolic extracts against baker's yeast (Saccharomyces cerevisiae) using the resazurin reduction test (RRT) and investigate their in vivo antiangiogenic activity through duck (Anas platyrhynchos) chorioallantoic membrane (CAM) assay. Both T. ornata and P. australis ethanolic extracts exhibited cytotoxic activities at $\mathrm{IC}_{50}$ of $530.53 \mathrm{ppm}$ and $528.78 \mathrm{ppm}$, respectively, and significant cytotoxicity was determined in $750 \mathrm{ppm}$ and $1000 \mathrm{ppm}$ concentrations of T. ornata and $1000 \mathrm{ppm}$ concentration of $P$. australis. Also, both T. ornata and $P$. australis ethanolic extracts exhibited antiangiogenic activity (100\% vascular inhibition) as all the concentrations of both species caused severe vascular damage in all the duck CAM samples treated. These results show the potential future application of these species for cytotoxic activities and vascular inhibition. The conduct of further tests using other model systems is recommended.
\end{abstract}

\section{Introduction}

Cellular proliferation is an important aspect of disease progression like cancer [1]. Angiogenesis, on the other hand, is the process of new blood vessel growth, which is involved in many pathological and physiological situations. Antiangiogenic therapy has become established as a strategy for the prevention of some illnesses, and many studies have been conducted on angiogenesis inhibitors because the aggravation of some pathogenesis, such as cancer, atherosclerosis, and diabetic retinopathy, is known to depend on the angiogenic phenotype [2]. Many food compounds have been believed to have advantage for human health due to their anticarcinogenic activity. Therefore, the cytotoxic and antiangiogenic activity of food components like brown macroalgae has received increased attention nowadays [3].

Macroalgae, also known as seaweed, is one of the most extensively used functional foods and medicinal herbs in many parts of the globe especially in Asian countries. It is known as functional food because of its richness in lipids
[4], minerals [5], and certain nutrients [6]. It also has several bioactive substances like polysaccharides [7], proteins [8], and polyphenols [9], with potential medicinal uses against cancer [10], inflammation [11], allergy [12], diabetes [13], thrombosis [14], obesity [15], lipidemia [16], hypertension [17], and other degenerative diseases.

Brown macroalgae species are widely studied for their potential pharmaceutical use. They are found to have antioxidant [18], antidiabetic [19, 20], anti-inflammatory [21], antiviral [22], antiproliferative [23], and anticoagulant [24] properties. The brown seaweeds are studied because they are rich in fucoidan and fucoxanthin [25]. These compounds are constantly reported to possess cytotoxic and antiangiogenic activities [26, 27]. Sargassum species are frequently studied for their antiangiogenic activity $[23,28,29]$. However, they are presently being regulated for harvest [30]. Thus, there is a need to screen more species of brown macroalgae for their cytotoxic and antiangiogenic effects.

Two of the common brown macroalgae species found in the coastal areas of Baybay City, Leyte, are Turbinaria 
ornata Agardh and Padina australis Hauck. As of the present knowledge, these species have only been studied for their anti-inflammatory $[31,32]$ and antibacterial $[33,34]$ activities. Thus, this study explored the potential of these two brown macroalgae species for their cytotoxicity and antiangiogenic activities.

\section{Materials and Methods}

2.1. Seaweed Collection. Around 100-200 g of T. ornata and $P$. australis was collected from the coastal areas of Maitum and Punta, Baybay City, Leyte, respectively, in March 2017. It is at this time when these seaweed species are at their mature stages and are in abundance in the areas. Upon collection, the seaweeds were washed thoroughly with seawater to remove epiphytes and other debris [19] and were then brought to the laboratory of the Department of Biological Sciences, Visayas State University.

2.2. Seaweed Identification. Identification of the seaweed species was based on the morphological analyses of the thalli (blades, holdfasts, etc.) following the book of Trono [35]. Prof. Dr. Humberto R. Montes, Jr., and Prof. Julissah C. Evangelio of the Institute of Tropical Ecology and Environmental Management and Department of Biological Sciences, Visayas State University, then validated the identifications. Voucher specimens were also deposited at the VSU Herbarium.

\subsection{Ethanolic Extraction and Preparation of Concentrations.} In the laboratory, the cleaned seaweeds were rinsed with tap water to remove excessive salts and were then ovendried at $50^{\circ} \mathrm{C}$ for $36-72 \mathrm{~h}$ [19]. The dried samples were powdered using mortar and pestle. Ten grams (10 g) of powdered samples was soaked in $100 \mathrm{~mL}$ of $100 \%$ ethanol for $24 \mathrm{~h}$ and was filtered using a filter paper (Whatman number 1, Sigma-Aldrich Inc.). The filtrate (crude ethanolic fraction) was concentrated at $40-50^{\circ} \mathrm{C}$ using a rotary evaporator $\left(\mathrm{RV}_{10}, \mathrm{IKA}^{\circledR}\right)$ [36]. A $1000 \mathrm{ppm}$ stock solution was prepared by dissolving $0.1 \mathrm{~g}$ of the extract in $100 \mathrm{~mL}$ of sterile distilled water. Concentrations of $750 \mathrm{ppm}$, $500 \mathrm{ppm}, 250 \mathrm{ppm}$, and $100 \mathrm{ppm}$ were then made from this solution.

2.4. Cytotoxicity Assay. The cytotoxicity of T. ornata and $P$. australis extracts was assayed through the resazurin reduction test (RRT) following the method of Tualla and Bitacura [37] with slight modification. This test is based on the ability of living cells to reduce the blue resazurin into pink resorufin. Treatments included in the assay were the different concentrations of $T$. ornata and $P$. australis ethanolic extracts. For the control set-up, distilled water served as the negative control while $0.1 \mathrm{M}$ of $\mathrm{CdCl}_{2}$ as the positive control. One point five grams ( $1.5 \mathrm{~g})$ of baker's yeast was activated by dissolving it in $40 \mathrm{~mL}$ sterile distilled water. This mixture was then diluted at $1: 100$. Fifty microliters $(50 \mu \mathrm{L})$ of baker's yeast cell suspension was pipetted and placed into the 96-well sterile microplate in triplicate. Then, $50 \mu \mathrm{L}$ of the treatments was added, and the cells were then incubated for an hour. Then, $10 \mu \mathrm{L}$ of resazurin solution was added into the wells starting from the negative control up to the positive control. After $12 \mathrm{~h}$, changes in color were observed and the absorbance of the different treatments was determined at $630 \mathrm{~nm}$ using a microplate reader (Heales $580 \mathrm{MB}$, Shenzhen Heales Technology Development Co. Ltd.) at the National Coconut Research Center (NCRC) Laboratory, Visayas State University, and the \% cytotoxicity of the treatments was computed using the following equation [38]:

$\%$ cytotoxicity $=\frac{\text { abs. of the treatment at } 630 \mathrm{~nm}}{\text { abs. of the positive control at } 630 \mathrm{~nm}} \times 100$.

2.5. Antiangiogenic Assay. The chorioallantoic membrane (CAM) assay was used in order to determine the antiangiogenic activity of the treatments. It was performed according to the method of Gururaj et al. [39] with modifications. Fertilized duck eggs were obtained from a commercial supplier in Brgy. Maganhan, Baybay, Leyte. Day 0 eggs (3 replicates) were placed in an incubator at $37^{\circ} \mathrm{C}$ at the Department of Animal Science, Visayas State University, Baybay, Leyte.

At the fifth day of incubation, the eggs were candled and inspected to determine the egg viability and the position of the embryo. The center of the eggshell outside the air sac was disinfected with $0.1 \%$ benzalkonium bromide by wiping its surface using sterile cotton. A $10 \mathrm{~mm}$ diameter window was gently drilled at the blunt end (air space) of the egg using a sterile dissecting needle. Two drops of $10 \% \mathrm{NaCl}$ solution were added adjacent to the CAM to moisten the inner shell membrane to easily separate the membrane from the CAM. The membrane and the CAM were separated without force after being clamped and raised using forceps. A window of $1 \mathrm{~cm}$ diameter was sectioned on the membrane to expose the vascular zone. Sterilized filter paper disks with a diameter of $7 \mathrm{~mm}$ were individually loaded with $5 \mu \mathrm{L}$ of seaweed ethanolic extracts and sterile distilled water (negative control). These were directly adhered to the vascular zone with the right density of blood vessels $[40,41]$. The inoculated CAMs were resealed with $3^{\prime \prime} \times 3^{\prime \prime}$ sterile plastic and returned to the incubator and was allowed to further develop [28]. After $24 \mathrm{~h}$, the eggs were reopened.

The CAM area was visually assessed for vascular damage. Representative areas or fractal segments were observed and photodocumented. The CAMs were scored using the CAM scoring guide by Raga et al. [42] with slight modification with 6 being the highest and 0 being the lowest score. CAM scores were set as follows: (6) severeblood vessels are completely damaged and are not visible anymore, (5) moderate-more than half of the vessel has been damaged, (4) slightly damaged-less than half of the vessel has been damaged, (3) minimal-small fractions are damaged, (2) hemorrhaging-increased blood flow is seen in capillaries, (1) ghost vessels-the capillary is already devoid of blood flow, and (0) no effect at all. Any damage on vasculature and obstruction to normal blood flow were 


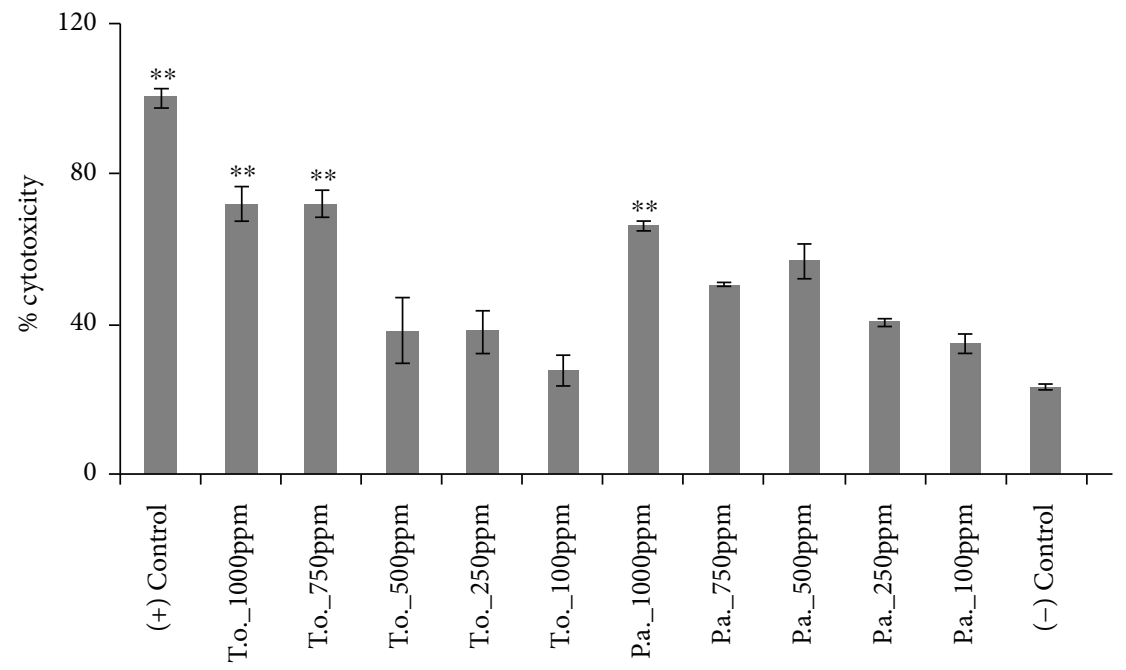

(a)

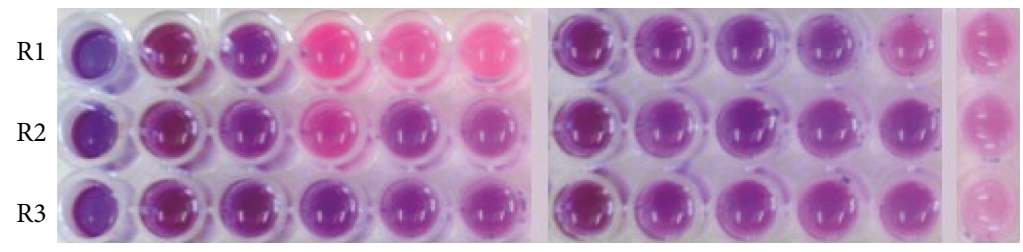

(b)

Figure 1: Cytotoxic activity of T. ornata and P. Australis ethanolic extracts on baker's yeast. (a) Comparison of the percent cytotoxicity (mean $\pm \mathrm{SE}$ ) of different concentrations of brown macroalgae ethanolic extracts against the positive control $\left(0.1 \mathrm{M} \mathrm{CdCl}_{2}\right)$ and the negative control (sterile distilled water). ${ }^{* *} p \leq 0.01$ indicates high significance (HSD). (b) Variations in color reactions in the triplicate wells of the different treatments after RRT. T.o.: Turbinaria ornata; P.a.: Padina australis.

considered positive antiangiogenic effect. Vascular inhibition (VI) was computed using the following formula:

$$
\% \mathrm{VI}=\frac{\text { number of blood vessels after treatment }}{\text { number of blood vessels before treatment }} \times 100 \text {. }
$$

2.6. Experimental Design and Analysis. This study followed a completely randomized design (CRD). One-way analysis of variance (ANOVA) was used to determine the significant difference of the treatments. Post hoc comparison was used to cluster the various treatments following Tukey's HSD. The results were considered significant at $p \leq 0.01$. Means were reported as mean $\pm \mathrm{SE}$.

\section{Results and Discussion}

Results of the RRT conducted showed that T. ornata and $P$. australis ethanolic extracts possess cytotoxic activity against yeast cells (Figures 1(a) and 1(b)). As shown in Figure 1(b), the cells treated with majority of the concentrations of the seaweed extracts did not change in color just like those treated with $0.1 \mathrm{M} \mathrm{CdCl}_{2}$ (positive control). This cytotoxic effect is only attributed to the seaweed extracts since the solvent used in preparing the different concentrations (negative control) did not exhibit cytotoxicity to the treated cells.

Since the variation in the colors of the different treatments was evident, it was decided to quantify the percent cytotoxicity of the treatments through their absorbance at $630 \mathrm{~nm}$. This quantified the amount of resazurin present in the treatment wells. This means that when the yeast cells are viable, they will be able to reduce blue resazurin to pink resorufin giving low absorbance at $630 \mathrm{~nm}$. On the other hand, when the treatments are toxic, there is a lesser ability of the yeast cells to reduce resazurin to resorufin giving higher absorbance at $630 \mathrm{~nm}$. Analysis revealed that strong cytotoxic activities were exhibited by $1000 \mathrm{ppm}$ and $750 \mathrm{ppm}$ of $T$. ornata and $1000 \mathrm{ppm}$ of P. Australis ethanolic extracts (Figure 1(a)). These are the treatments that showed highly significant difference against the negative control and no significant difference against the positive control.

Furthermore, in order to compare the cytotoxicity of the two brown macroalgae species, their concentrations that could kill $50 \%$ of the treated cells $\left(\mathrm{IC}_{50}\right)$ were determined (Figure 2). $\mathrm{IC}_{50}$ values for $T$. ornata and $P$. australis on yeast cells were determined at $530.53 \mathrm{ppm}$ and 528.78 ppm, respectively. Lower $\mathrm{IC}_{50}$ value means high cytotoxicity of the seaweed ethanolic extracts against yeast cells. The difference in the $\mathrm{IC}_{50}$ values of the ethanolic 


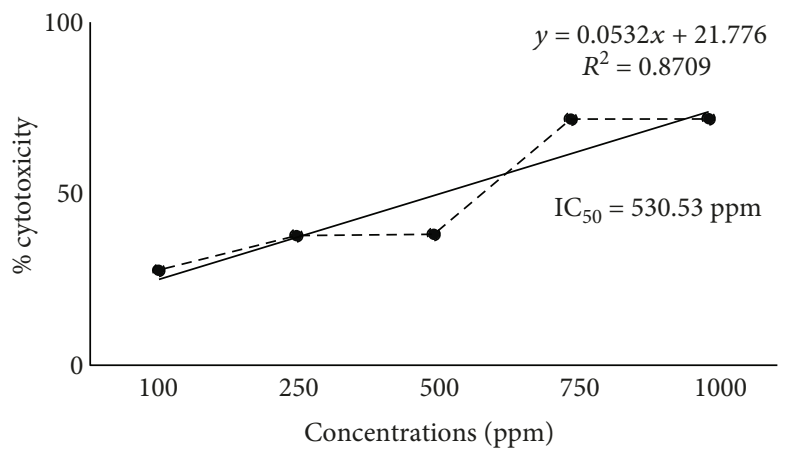

(a)

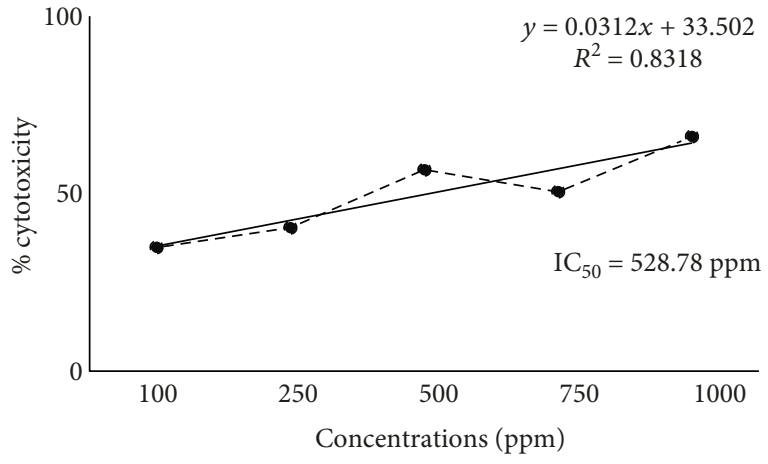

(b)

FIGURE 2: $\mathrm{IC}_{50}$ computations for the comparison of the $\%$ cytotoxicity between T. ornata (a) and P. australis (b) under different concentrations of ethanolic extracts.

TABle 1: Antiangiogenic activity of T. ornata and P. australis ethanolic extracts as revealed by the CAM assay.

\begin{tabular}{|c|c|c|c|c|}
\hline \multicolumn{2}{|l|}{ Treatments } & \multirow{2}{*}{$\begin{array}{c}\text { Vascular inhibition (\%) } \\
0\end{array}$} & \multirow{2}{*}{$\begin{array}{c}\text { Vascular damage score } \\
0\end{array}$} & \multirow{2}{*}{$\begin{array}{c}\text { Description of vascular damage } \\
\text { No vascular inhibition }\end{array}$} \\
\hline Negative cor & e distilled water) & & & \\
\hline & $1000 \mathrm{ppm}$ & 100 & 6 & Severely damaged \\
\hline & 750 ppm & 100 & 6 & Severely damaged \\
\hline \multirow[t]{5}{*}{ T. ornata } & $500 \mathrm{ppm}$ & 100 & 6 & Severely damaged \\
\hline & $250 \mathrm{ppm}$ & 100 & 6 & Severely damaged \\
\hline & $100 \mathrm{ppm}$ & 100 & 6 & Severely damaged \\
\hline & $1000 \mathrm{ppm}$ & 100 & 6 & Severely damaged \\
\hline & $750 \mathrm{ppm}$ & 100 & 6 & Severely damaged \\
\hline \multirow[t]{3}{*}{ P. australis } & $500 \mathrm{ppm}$ & 100 & 6 & Severely damaged \\
\hline & $250 \mathrm{ppm}$ & 100 & 6 & Severely damaged \\
\hline & $100 \mathrm{ppm}$ & 100 & 6 & Severely damaged \\
\hline
\end{tabular}

extracts of $P$. australis and $T$. ornata is very slim which could mean no difference in their cytotoxic activity at all.

Moreover, the result of the CAM assay revealed 100\% vascular inhibition on all concentrations of both seaweed ethanolic extracts. These results were significantly different with those treated with only sterile distilled water (negative control). This implies that the antiangiogenic activity of the different seaweed concentrations is solely attributed to the extracts and not to the solvent used (Table 1). However, it is believed that a trend could be observed in the antiangiogenic activity if the CAMs are subjected to much lower concentrations of the extracts.

It was observed that treatment of CAM blood vessels with sterile distilled water (negative control) shows no effect or any damage on the blood vessels (Figure 3(a)), hence attaining a score of 0 (Table 1). On the other hand, the blood vessels were severely damaged and were not visible anymore after 24 hours of administration of T. ornata and P. australis ethanolic extracts in all concentrations (Figure 3(b)), hence attaining a score of 6 (Table 1). This means that the ethanolic extracts of both seaweeds possess antiangiogenic activity but were not elaborately compared because the effects were uniform in all the concentrations. In the CAM, angiogenic and angiostatic responses to promoters or inhibitors, respectively, are readily visible. When angiogenic substances are administered to the CAM, there is a visible increase in the density of blood vessels around the implant. On the other hand, administering an antiangiogenic substance into the CAM will make vessels become less dense around the implant, and eventually these vessels disappear [43].

The cytotoxic and antiangiogenic activities of T. ornata and $P$. australis could be due to the presence of phenolic compounds, fucoxanthin and fucoidan, in these brown macroalgae species as previously reported $[44,45]$. Phenolic compounds have antioxidant properties which are important in combatting the effects of oxidative stress-influenced cancer development involving malignant transformation due to DNA mutations. Namvar et al. [23] reported that cytotoxic activity of the brown algae is positively correlated with its total phenolic contents.

On the other hand, fucoxanthin is a well-known example of natural pigment for anticancer activity [46]. Other research reported on free radical-scavenging activity of fucoxanthin as suggested to be the underlying mechanism for its cytotoxic effect [46]. And an in vitro and in vivo study done by Kim and colleagues [47] showed that fucoxanthin displays 
Sterile distilled $\mathrm{H}_{2} \mathrm{O}$
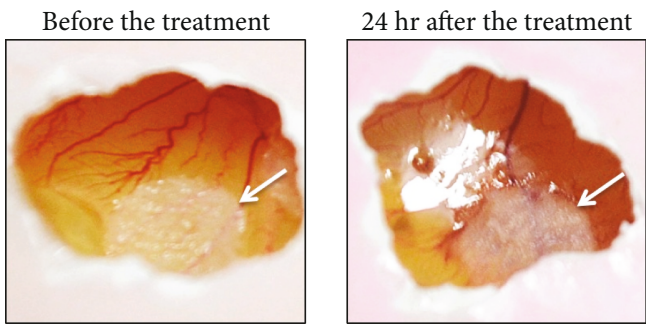

(a)

T. ornata

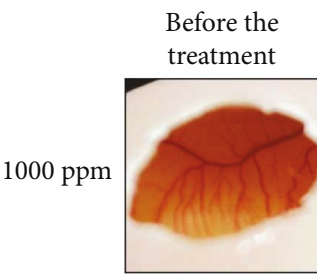

$24 \mathrm{hr}$ after the treatment
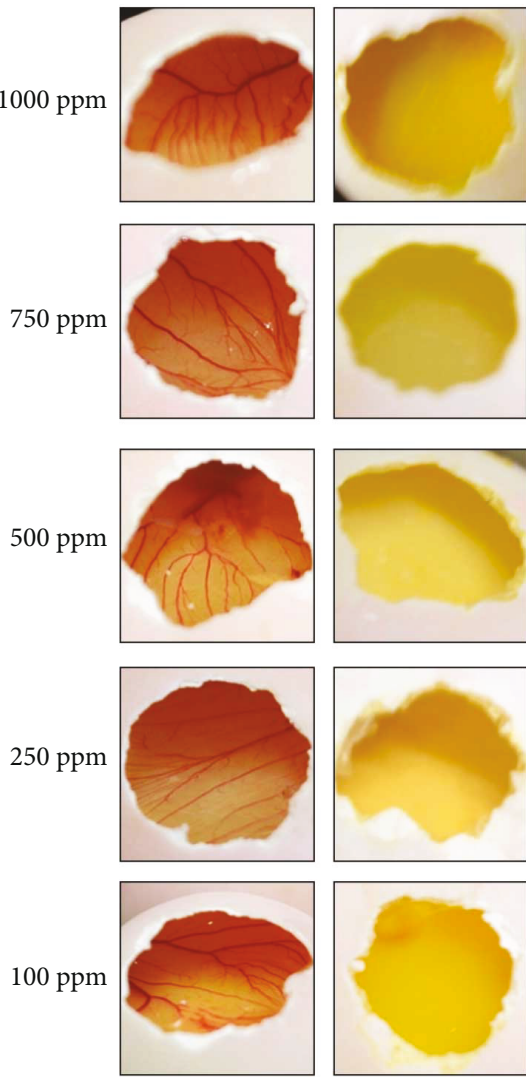

P. australis
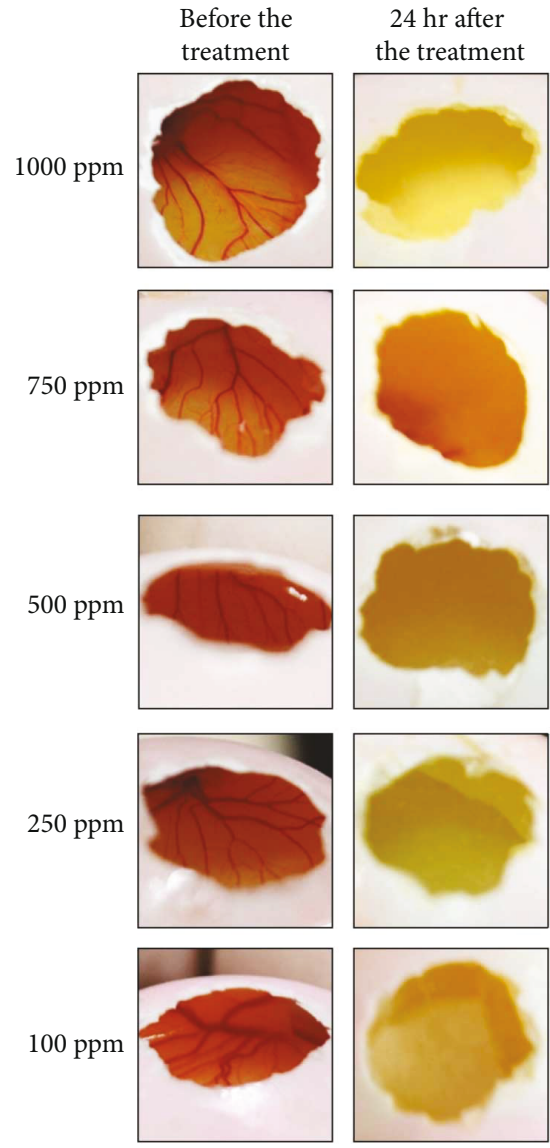

(b)

Figure 3: Representative samples of duck CAM before and after treatment of (a) sterile distilled water as the negative control (the arrow points to the placement of the filter paper disks impregnated with the treatment) and (b) different concentrations of T. ornata and $P$. australis ethanolic extracts.

inhibitory effect on tumor growth on B16F10 cells. Another study showed that fucoxanthin has cytotoxic effect and strong antitumor potential as exhibited by its inhibitory effect on liver tumorigenesis [48]. Sugawara et al. [29] also reported that fucoxanthin derived from brown seaweed has the antiangiogenic properties via restraining tube formation of the endothelial cells of the umbilical vein.

Furthermore, fucoidan has been constantly reported for its ability to inhibit tumor formation and metastasis $[49,50]$. A study of Koyanagi et al. [51] showed that fucoidan possessed strong inhibitory effect on tube formation of the human umbilical vein, while another study showed significant antiangiogenic activity on human uterine carcinoma HeLa cells suggesting that the antiangiogenic effects may be explained, at least partially, by the antioxidative potential of fucoidan extracts [52]. However, a study conducted by Liu et al. [53] revealed that fucoidan from Undaria pinnatifida, also a brown macroalgae species, has restraining effects on cellular proliferation and immigration and the formation of the vessel network and that it also decreased the growth of the blood vessels and decreased the expression of VEGF-A angiogenesis factor.

Fucoxanthin, similar to fucoidan, is not uniform, and its structure highly differs on the species source of isolation; 
hence, different species of brown macroalgae exhibit different cytotoxic and antiangiogenic activities [21, 46, 54]. One study, for instance, showed that $T$. ornata possesses free radical-scavenging properties due to the high polyphenol content (fucoidan and fucoxanthin) [55], while a study on $P$. australis also revealed the seaweeds' antioxidant activity which is attributed to the presence of different secondary metabolites such as phenolic compounds and carotenoids further suggesting that the mechanism could be due to their individual or collective participation [56].

Other cytotoxicity studies on macroalgae extracted using various polar solvents reveal different cytotoxic activities of seaweed extracts against cell lines. A study conducted by Tantengco et al. [57] reveals that crude extracts of Kappaphycus alvarezii and Eucheuma denticulatum have strong inhibitory concentrations at $42.62 \mathrm{ppm}$ and $44.12 \mathrm{ppm}$ against human cancer cell lines, respectively. Another study by Spavieri et al. [58] showed active cytotoxicity of Halidrys siliquosa and Bifurcaria bifurcata on Trypanosoma brucei with $\mathrm{IC}_{50}$ values of 1.2 and $1.9 \mu \mathrm{g} / \mathrm{mL}$, respectively. The same difference in cytotoxic activities was observed from extracts of brown macroalgae species. This denotes further that inhibitory concentrations of seaweed extracts against different cell lines or model organisms also differ.

\section{Conclusion}

The ocean has been considered a rich source of compounds possessing novel structures and biological activities. Biologically active molecules isolated from marine organisms have been explored for their applications in pharmaceuticals, nutritional supplements, cosmetics, agrochemicals, molecular probes, and enzymes. This study likewise shows that $T$. ornata and $P$. australis ethanolic extracts have cytotoxic and antiangiogenic properties. These results imply that $T$. ornata and $P$. australis ethanolic extracts have the potential future application for inhibiting cell proliferation and vascular formation. It is recommended however that lower concentrations of the extracts be tested to acquire the $\mathrm{IC}_{50}$ for their antiangiogenic activities. The use of other solvents, tests (i.e., MTT assay), and other model systems (i.e., rat aorta) in further studies is recommended as well.

\section{Data Availability}

The data used to support the findings of this study are available from the corresponding author upon request.

\section{Conflicts of Interest}

The authors declare that they have no conflicts of interest.

\section{Acknowledgments}

The authors are grateful to Mr. Ivan Patrick B. Tualla for giving the resazurin, to Professor Dr. Humberto R. Montes, Jr., of the Institute of Tropical Ecology and Environmental Management of Visayas State University for verifying the identification of the seaweed species, also to Mr. Ris Menoel R. Modina, Professor Julissah C. Evangelio, and Professor Dr. Analyn M. Mazo of the Department of Biological Sciences, Visayas State University, for their critical reading of the manuscript, and to Professor Dr. Dinah Espina of the Department of Animal Science and Professor Tessie Nuñez of the National Abaca Research Center of Visayas State University for allowing the use of their laboratory facility.

\section{References}

[1] J. Caroll, "Cell division and cancer. Nature education," 2014, May 2017, https://www.nature.com/scitable/topicpage/ cell-division-and-cancer-14046590.

[2] N. Ferrara and R. S. Kerbel, "Angiogenesis as a therapeutic target," Nature, vol. 438, no. 7070, pp. 967-974, 2005.

[3] Y. Cao, R. Cao, and E. Brakenhielm, "Antiangiogenic mechanisms of diet-derived polyphenols," The Journal of Nutritional Biochemistry, vol. 13, no. 7, pp. 380-390, 2002.

[4] J. Debbarma, B. Madhusudana Rao, L. N. Murthy, S. Mathew, G. Venkateshwarlu, and C. N. Ravishankar, "Nutritional profiling of the edible seaweeds Gracilaria edulis, Ulva lactuca and Sargassum sp.," Indian Journal of Fisheries, vol. 63, no. 3, 2016.

[5] P. MacArtain, C. I. R. Gill, M. Brooks, R. Campbell, and I. R. Rowland, "Nutritional value of edible seaweeds," Nutrition Reviews, vol. 65, no. 12, pp. 535-543, 2007.

[6] P. Prabhasankar, P. Ganesan, and N. Bhaskar, "Influence of Indian brown seaweed (Sargassum marginatum) as an ingredient on quality, biofunctional, and microstructure characteristics of pasta," Food Science and Technology International, vol. 15, no. 5, pp. 471-479, 2009.

[7] T. Barahona, N. P. Chandía, M. V. Encinas, B. Matsuhiro, and E. A. Zúñiga, "Antioxidant capacity of sulfated polysaccharides from seaweeds. A kinetic approach," Food Hydrocolloids, vol. 25, no. 3, pp. 529-535, 2011.

[8] D. I. Sánchez-Machado, J. López-Cervantes, J. LópezHernández, and P. Paseiro-Losada, "Fatty acids, total lipid, protein and ash contents of processed edible seaweeds," Food Chemistry, vol. 85, no. 3, pp. 439-444, 2004.

[9] Q. Zhang, J. Zhang, J. Shen, A. Silva, D. A. Dennis, and C. J. Barrow, "A simple 96-well microplate method for estimation of total polyphenol content in seaweeds," Journal of Applied Phycology, vol. 18, no. 3-5, pp. 445-450, 2006.

[10] S. Alam, D. Katiyar, R. Goel, A. Vats, and A. Mittal, "Role of herbals in cancer management," The Journal of Phytopharmacology, vol. 2, no. 6, pp. 46-51, 2013.

[11] M. N. Khan, J. S. Choi, M. C. Lee et al., "Anti-inflammatory activities of methanol extracts from various seaweed species," Journal of Environmental Biology, vol. 29, no. 4, pp. 465469, 2008.

[12] A. W. Zuercher, R. Fritsché, B. Corthésy, and A. Mercenier, "Food products and allergy development, prevention and treatment," Current Opinion in Biotechnology, vol. 17, no. 2, pp. 198-203, 2006.

[13] F. Nwosu, J. Morris, V. A. Lund, D. Stewart, H. A. Ross, and G. J. McDougall, "Anti-proliferative and potential anti-diabetic effects of phenolic-rich extracts from edible marine algae," Food Chemistry, vol. 126, no. 3, pp. 10061012, 2011. 
[14] C. Fitzgerald, E. Gallagher, D. Tasdemir, and M. Hayes, "Heart health peptides from macroalgae and their potential use in functional foods," Journal of Agricultural and Food Chemistry, vol. 59, no. 13, pp. 6829-6836, 2011.

[15] K. Miyashita, "The carotenoid fucoxanthin from brown seaweed affects obesity," Lipid Technology, vol. 21, no. 8-9, pp. 186-190, 2009.

[16] S. Mohamed, S. N. Hashim, and H. A. Rahman, "Seaweeds: a sustainable functional food for complementary and alternative therapy," Trends in Food Science \& Technology, vol. 23, no. 2, pp. 83-96, 2012.

[17] K. Wada, K. Nakamura, Y. Tamai et al., "Seaweed intake and blood pressure levels in healthy pre-school Japanese children," Nutrition Journal, vol. 10, no. 1, p. 83, 2011.

[18] Y. Athukorala, K.-N. Kim, and Y.-J. Jeon, "Antiproliferative and antioxidant properties of an enzymatic hydrolysate from brown alga, Ecklonia cava," Food and Chemical Toxicology, vol. 44, no. 7, pp. 1065-1074, 2006.

[19] Y. X. Chin, P. E. Lim, C. A. Maggs, S. M. Phang, Y. Sharifuddin, and B. D. Green, "Anti-diabetic potential of selected Malaysian seaweeds," Journal of Applied Phycology, vol. 27, no. 5, pp. 2137-2148, 2015.

[20] J.-H. Oh, J. Kim, and Y. Lee, "Anti-inflammatory and antidiabetic effects of brown seaweeds in high-fat diet-induced obese mice," Nutrition Research and Practice, vol. 10, no. 1, pp. 42-48, 2016.

[21] A. Cumashi, N. A. Ushakova, M. E. Preobrazhenskaya et al., "A comparative study of the anti-inflammatory, anticoagulant, antiangiogenic, and antiadhesive activities of nine different fucoidans from brown seaweeds," Glycobiology, vol. 17, no. 5, pp. 541-552, 2007.

[22] P. Mandal, C. G. Mateu, K. Chattopadhyay, C. A. Pujol, E. B. Damonte, and B. Ray, "Structural features and antiviral activity of sulphated fucans from the brown seaweed Cystoseira indica," Antiviral Chemistry and Chemotherapy, vol. 18, no. 3, pp. 153-162, 2007.

[23] F. Namvar, R. Mohamad, J. Baharara, S. Zafar-Balanejad, F. Fargahi, and H. S. Rahman, "Antioxidant, antiproliferative, and antiangiogenesis effects of polyphenol-rich seaweed (Sargassum muticum)," BioMed Research International, vol. 2013, Article ID 604787, 9 pages, 2013.

[24] M. de Zoysa, C. Nikapitiya, Y.-J. Jeon, Y. Jee, and J. Lee, “Anticoagulant activity of sulfated polysaccharide isolated from fermented brown seaweed Sargassum fulvellum," Journal of Applied Phycology, vol. 20, no. 1, pp. 67-74, 2008.

[25] L. Chevolot, B. Mulloy, J. Ratiskol, A. Foucault, and S. ColliecJouault, "A disaccharide repeat unit is the major structure in fucoidans from two species of brown algae," Carbohydrate Research, vol. 330, no. 4, pp. 529-535, 2001.

[26] A. Asai, T. Sugawara, H. Ono, and A. Nagao, "Biotransformation of fucoxanthinol into amarouciaxanthin $\mathrm{A}$ in mice and HepG2 cells: formation and cytotoxicity of fucoxanthin metabolites," Drug Metabolism and Disposition, vol. 32, no. 2, pp. 205-211, 2004.

[27] C. Ishikawa, S. Tafuku, T. Kadekaru et al., “Antiadult T-cell leukemia effects of brown algae fucoxanthin and its deacetylated product, fucoxanthinol," International Journal of Cancer, vol. 123, no. 11, pp. 2702-2712, 2008.

[28] P. F. Dias, J. M. Siqueira Jr., M. Maraschin, A. G. Ferreira, A. R. Gagliardi, and R. M. Ribeiro-do-Valle, "A polysaccharide isolated from the brown seaweed Sargassum stenophyllum exerts antivasculogenic effects evidenced by modified morphogenesis," Microvascular Research, vol. 75, no. 1, pp. 34-44, 2008.

[29] T. Sugawara, K. Matsubara, R. Akagi, M. Mori, and T. Hirata, "Antiangiogenic activity of brown algae fucoxanthin and its deacetylated product, fucoxanthinol," Journal of Agricultural and Food Chemistry, vol. 54, no. 26, pp. 9805-9810, 2006.

[30] Department of Agriculture, "Fisheries Administraton Order No. 250, series of 2014," May 2017, http://www.bfar.da.gov. ph/LAW?fi=429\#post.

[31] S. Ananthi, H. R. B. Raghavendran, A. G. Sunil, V. Gayathri, G. Ramakrishnan, and H. R. Vasanthi, "In vitro antioxidant and in vivo anti-inflammatory potential of crude polysaccharide from Turbinaria ornata (marine brown alga)," Food and Chemical Toxicology, vol. 48, no. 1, pp. 187-192, 2010.

[32] N. K. Praveen and K. Chakraborty, "Antioxidant and antiinflammatory potential of the aqueous extract and polysaccharide fraction from brown marine macroalgae Padina sp. from Gulf of Mannar of Peninsular India," Journal of Coastal Life Medicine, vol. 1, no. 1, pp. 39-49, 2013.

[33] C. W. Chong, S. L. Hii, and C. L. Wong, "Antibacterial activity of Sargassum polycystum C. Agardh and Padina australis Hauck (Phaeophyceae)," African Journal of Biotechnology, vol. 10, no. 64, pp. 14125-14131, 2011.

[34] M. Zubia, C. Payri, and E. Deslandes, "Alginate, mannitol, phenolic compounds and biological activities of two rangeextending brown algae, Sargassum mangarevense and Turbinaria ornata (Phaeophyta: Fucales), from Tahiti (French Polynesia)," Journal of Applied Phycology, vol. 20, no. 6, pp. 1033-1043, 2008.

[35] G. Trono, Field Guide and Atlas of the Seaweed Resources of the Philippines, Bookmark, Inc., Makati, Philippines, 1997.

[36] R. J. Canoy, J. M. Lomanta, P. M. Ballesteros, E. A. Chun, R. P. Dator, and S. D. Jacinto, "Cancer chemotherapeutic potential of endemic and indigenous plants of Kanawan, Morong, Bataan Province, Philippines," Asia Life SciencesThe Asian International Journal of Life Sciences, vol. 20, no. 2, pp. 331-339, 2011.

[37] I. P. B. Tualla and J. G. Bitacura, "Effects of cadmium and zinc on the gamete viability, fertilization, and embryonic development of Tripneustes gratilla (Linnaeus)," Scientifica, vol. 2016, Article ID 8175213, 10 pages, 2016.

[38] S. Mashjoor, M. Yousefzadi, M. A. Esmaeili, and R. Rafiee, "Cytotoxicity and antimicrobial activity of marine macro algae (Dictyotaceae and Ulvaceae) from the Persian Gulf," Cytotechnology, vol. 68, no. 5, pp. 1717-1726, 2016.

[39] A. E. Gururaj, M. Belakavadi, and B. P. Salimath, "Antiangiogenic effects of butyric acid involve inhibition of VEGF/ KDR gene expression and endothelial cell proliferation," Molecular and Cellular Biochemistry, vol. 243, no. 1-2, pp. 107-112, 2003.

[40] Z. Chen, Y. Zhang, C. Jia et al., "mTORC1/2 targeted by n-3 polyunsaturated fatty acids in the prevention of mammary tumorigenesis and tumor progression," Oncogene, vol. 33, no. 37, pp. 4548-4557, 2014.

[41] Z.-H. Wen, Y. C. Su, P. L. Lai et al., "Critical role of arachidonic acid-activated mTOR signaling in breast carcinogenesis and angiogenesis," Oncogene, vol. 32, no. 2, pp. 160-170, 2013.

[42] D. D. Raga, A. B. Alimboyoguen, C. C. Shen, A. A. Herrera, and C. Y. Ragasa, "Triterpenoids and an anti-angiogenic sterol from Ardisia pyramidalis (Cav.) Pers," The Philippine Agricultural Scientist, vol. 94, no. 2, pp. 213-220, 2011. 
[43] D. Ribatti and E. Crivellato, "Mast cells and tumours," in Mast Cells and Tumours, pp. 83-88, Springer, Dordrecht, Netherlands, 2011.

[44] S. Lakshmanasenthil, T. Vinothkumar, D. Geetharamani, T. Marudhupandi, G. Suja, and N. S. Sindhu, "Fucoidan-a novel $\alpha$-amylase inhibitor from Turbinaria ornata with relevance to NIDDM therapy," Biocatalysis and Agricultural Biotechnology, vol. 3, no. 3, pp. 66-70, 2014.

[45] Y. Yuguchi, V. T. T. Tran, L. M. Bui et al., "Primary structure, conformation in aqueous solution, and intestinal immunomodulating activity of fucoidan from two brown seaweed species Sargassum crassifolium and Padina australis," Carbohydrate Polymers, vol. 147, pp. 69-78, 2016.

[46] S. Zorofchian Moghadamtousi, H. Karimian, R. Khanabdali et al., "Anticancer and antitumor potential of fucoidan and fucoxanthin, two main metabolites isolated from brown algae," The Scientific World Journal, vol. 2014, Article ID 768323, 10 pages, 2014.

[47] K.-N. Kim, G. Ahn, S.-J. Heo et al., "Inhibition of tumor growth in vitro and in vivo by fucoxanthin against melanoma B16F10 cells," Environmental Toxicology and Pharmacology, vol. 35, no. 1, pp. 39-46, 2013.

[48] S. K. Das, T. Hashimoto, and K. Kanazawa, "Growth inhibition of human hepatic carcinoma HepG2 cells by fucoxanthin is associated with down-regulation of cyclin D," Biochimica et Biophysica Acta (BBA) - General Subjects, vol. 1780, no. 4, pp. 743-749, 2008.

[49] S. Ermakova, R. Sokolova, S.-M. Kim, B.-H. Um, V. Isakov, and T. Zvyagintseva, "Fucoidans from brown seaweeds Sargassum hornery, Eclonia cava, Costaria costata: structural characteristics and anticancer activity," Applied Biochemistry and Biotechnology, vol. 164, no. 6, pp. 841-850, 2011.

[50] T.-H. Huang, Y.-H. Chiu, Y.-L. Chan et al., "Prophylactic administration of fucoidan represses cancer metastasis by inhibiting vascular endothelial growth factor (VEGF) and matrix metalloproteinases (MMPs) in Lewis tumor-bearing mice," Marine Drugs, vol. 13, no. 4, pp. 1882-1900, 2015.

[51] S. Koyanagi, N. Tanigawa, H. Nakagawa, S. Soeda, and H. Shimeno, "Oversulfation of fucoidan enhances its antiangiogenic and antitumor activities," Biochemical Pharmacology, vol. 65, no. 2, pp. 173-179, 2003.

[52] J. Ye, Y. Li, K. Teruya et al., "Enzyme-digested fucoidan extracts derived from seaweed Mozuku of Cladosiphon novae-caledoniae kylin inhibit invasion and angiogenesis of tumor cells," Cytotechnology, vol. 47, no. 1-3, pp. 117126, 2005.

[53] F. Liu, J. Wang, A. K. Chang et al., "Fucoidan extract derived from Undaria pinnatifida inhibits angiogenesis by human umbilical vein endothelial cells," Phytomedicine, vol. 19, no. 8-9, pp. 797-803, 2012.

[54] S. K. Das, T. Hashimoto, K. Shimizu et al., "Fucoxanthin induces cell cycle arrest at $G_{0} / G_{1}$ phase in human colon carcinoma cells through up-regulation of $21^{\text {WAF1/Cip1," }}$ Biochimica et Biophysica Acta (BBA) - General Subjects, vol. 1726, no. 3, pp. 328-335, 2005.

[55] P. Vijayabaskar and V. Shiyamala, “Antioxidant properties of seaweed polyphenol from Turbinaria ornata (Turner) J. Agardh, 1848," Asian Pacific Journal of Tropical Biomedicine, vol. 2, no. 1, pp. S90-S98, 2012.

[56] M. C. Hongayo, R. C. Larino, and D. L. Malingin, “Antibacterial and antioxidant effects of brown alga Padina australis
Hauck crude extract," IAMURE International Journal of Science and Clinical Laboratory, vol. 2, no. 1, 2012.

[57] G. O. A. Tantengco, A. C. Limbo, E. M. N. Montaño, and D. S. Jacinto, "Cytotoxic activity of crude extract and fractions from Sargassum siliquosum (JG Agardh) and other seaweeds against selected human cancer cell lines," International Journal of Biosciences, vol. 7, no. 2, pp. 207-215, 2015.

[58] J. Spavieri, A. Allmendinger, M. Kaiser et al., "Antimycobacterial, antiprotozoal and cytotoxic potential of twenty-one brown algae (Phaeophyceae) from British and Irish waters," Phytotherapy Research, vol. 24, no. 11, pp. 1724-1729, 2010. 


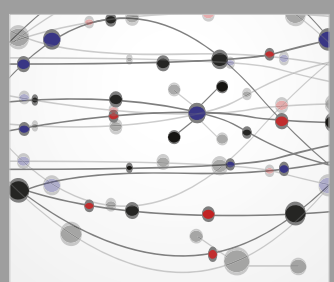

The Scientific World Journal
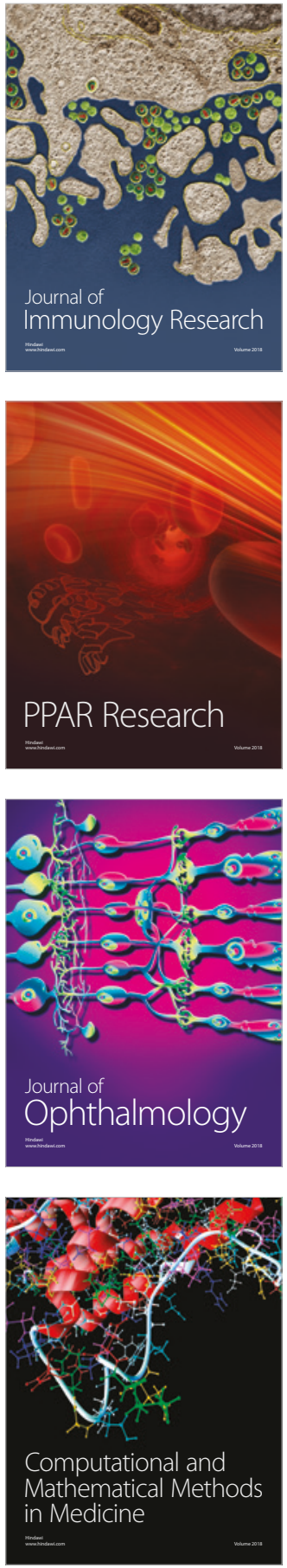

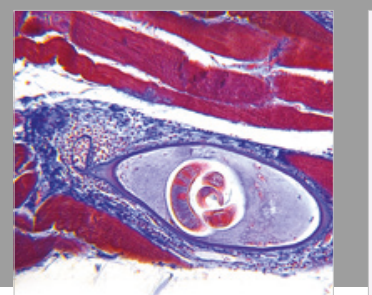

Gastroenterology Research and Practice

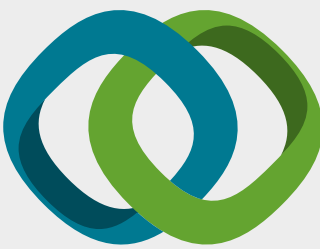

\section{Hindawi}

Submit your manuscripts at

www.hindawi.com
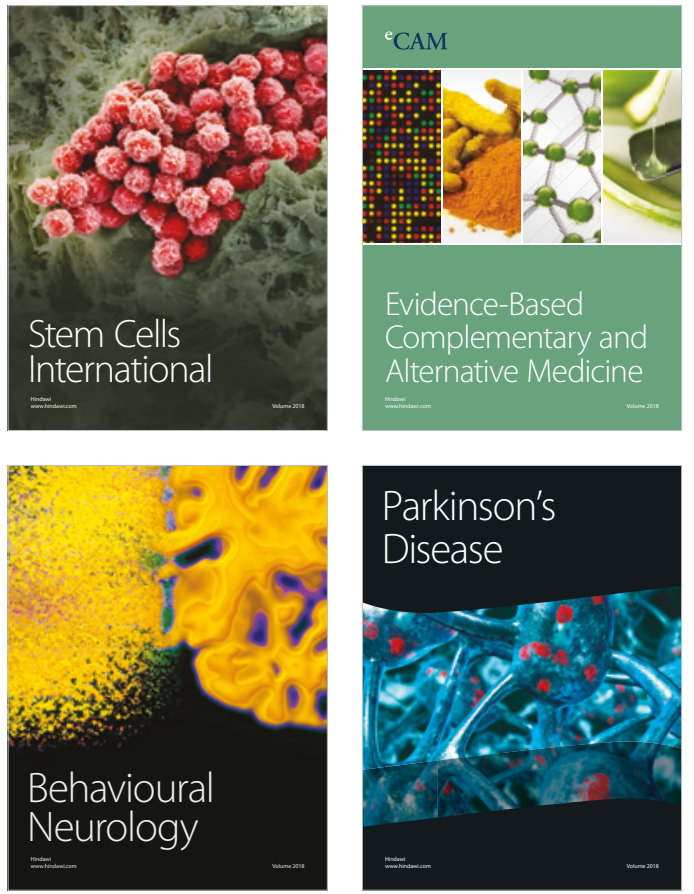

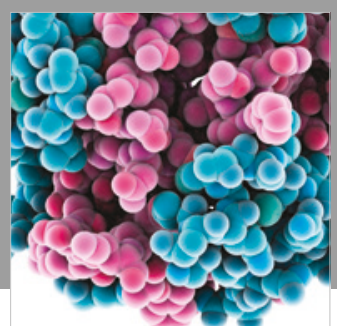

ournal of

Diabetes Research

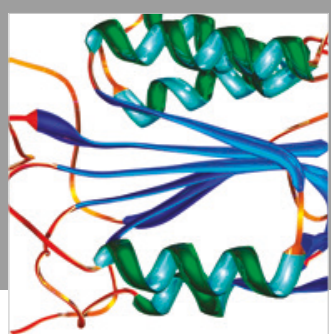

Disease Markers
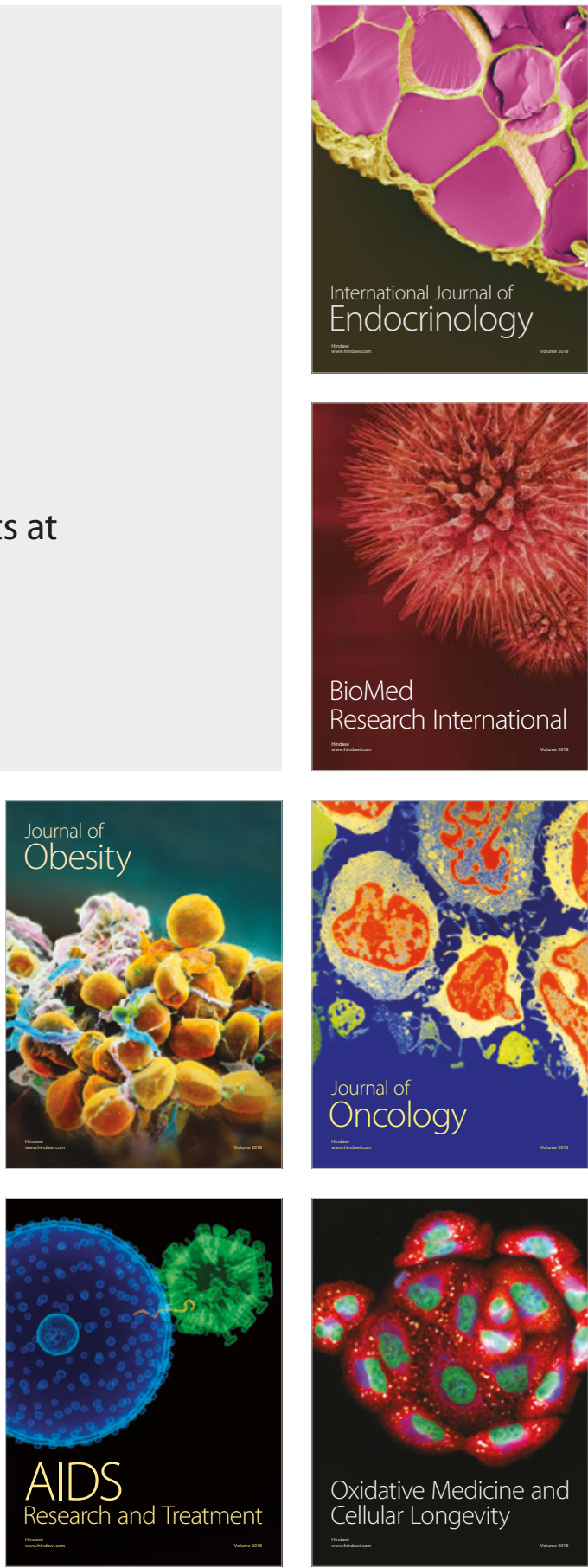